\title{
Cribellate Spider, Metaltella simoni (Keyserling) (Arachnida: Araneae: Amphinectidae) ${ }^{1}$
}

\author{
G. B. Edwards ${ }^{2}$
}

\section{Introduction}

Metaltella simoni (Keyserling) is a relatively recent introduction to the Florida spider fauna. Although it is generally inconspicuous, $M$. simoni may be a threat to extirpate the Florida population of our native amaurobioid species, Titanoeca brunnea Emerton.

\section{Distribution}

Originally known from Argentina, southern Brazil, and Uruguay, $M$. simoni was subsequently imported into the southern United States. The first known record for this species in the U.S. is 23-30 July 1944, from Harahan, Louisiana. The most recent revision of North American Amaurobioidae (the families in which Metalella and Titanoeca were formally found, Leech 1972) gives the following known U.S. records (by county): Florida (Bay County); Louisiana (East Baton Rouge, Orleans, and St. Tammany Parishes); and Mississippi (Jackson and Pearl River Counties). The published Florida record is from St. Andrews State Park, 28 March 1966, two females collected by J.A. Beatty, under board in open sandy area at edge of woods. A second, previously unpublished, Florida record is from Liberty County, Torreya State Park, 7 June 1977, one male collected by J.A. Beatty (personal communication).

The Florida State Collection of Arthropods (FSCA) has over 30 separate collections of M. simoni from Florida. Most of these records are from Gainesville in Alachua County. The earliest such collection is 22 February 1981, one female taken by G.B. Edwards in a web under pine bark. Many of the Gainesville records are from the Doyle Conner Building prior to the initiation of a regular fumigation program.

A few records exist in Florida south of Alachua County. A female M. simoni was collected in Orange County, Lake Buena Vista, 3 February 1982, by J. Atwood, in a shipment of Jacaranda acutifolia Humb. \& Bonpl. plants from California. As no records of this spider are known from California, it is likely that the spider entered the shipment after it arrived in Florida. Three juvenile specimens which appear to be $M$. simoni have also been found. A penultimate male was captured in Volusia County, Samsula, 4 February

1. This document is EENY-322 (originally published as DPI Entomology Circular 354), one of a series of Featured Creatures from the Entomology and Nematology Department, Florida Cooperative Extension Service, Institute of Food and Agricultural Sciences, University of Florida. Published: May 2004. This document is also available on Featured Creatures Website at http://creatures.ifas.ufl.edu. Please visit the EDIS Website at http://edis.ifas.ufl.edu. Additional information on these organisms, including many color photographs, is available at the Entomology and Nematology Department website at http://entnemdept.ifas.ufl.edu/.

2. G. B. Edwards, Florida Department of Agriculture and Consumer Services, Division of Plant Industry, Gainesville, FL.

The Institute of Food and Agricultural Sciences (IFAS) is an Equal Employment Opportunity - Affirmative Action Employer authorized to provide research, educational information and other services only to individuals and institutions that function without regard to race, creed, color, religion, age, disability, sex, sexual orientation, marital status, national origin, political opinions or affiliations. For information on obtaining other extension publications, contact your county Cooperative Extension Service office. Florida Cooperative Extension Service / Institute of Food and Agricultural Sciences / University of Florida / Larry R. Arrington, Interim Dean 
1980, by J.N. Pott, on Draceana sp. An immature female was collected in Brevard County, Titusville, 22 February 1986, by A. Baker. Another penultimate male was found in Lee County, Alva, 28 August 1981, by C. Scharfenberg, on pothos, Epipremnum aureum (Linden \& Andre) Bunt.

Recent surveys of arachnid populations from various Florida plant communities (e.g., Corey and Taylor, 1988, 1989; Corey et al. 1991) have been useful for recording the presence of particular species. Florida records for $M$. simoni collected by D.T. Corey are as follows: one female, Suwannee County, Suwannee River State Park, 1 May 1987; one female, Alachua County, Gainesville, 10 July 1987; five males, one female, Polk County, Lake Wales, 14 November 1986; one female, also from Lake Wales, 11 November 1987. All of these specimens were taken from pitfall traps.

Based on the above records, it appears that $M$. simoni has spread steadily eastward and southward into Florida since it was first collected in the state in 1966. Its synanthropic habits are well documented by its frequent occurrence in buildings and, to a lesser extent, on ornamental plants. However, several records of feral individuals indicate that it is equally at home away from human habitations. Leech (1972) noted that $M$. simoni is quite common in Mississippi and parts of Louisiana in the wild.

\section{Description}

Leech (1972) redescribed both $M$. simoni and $T$. brunnea. Males of M. simoni are 7.0 to $8.5 \mathrm{~mm}$ in length, whereas females are 8 to $9 \mathrm{~mm}$ in length. Males have the carapace (darker anteriorly) and legs (darker distally) yellow to yellow-orange, but these structures in the female are brown. Both sexes have the abdomen mottled gray with four irregular white stripes on the venter. $M$. simoni is the only amaurobioid in the Nearctic region with five to six teeth on both the pro- and retromargins of the chelicerae. All other amaurobiid species in this geographic area have four or fewer teeth on each cheliceral margin.

Males of $T$. brunnea are 4 to $5 \mathrm{~mm}$ in length; females only a slightly larger 4.5 to $5.5 \mathrm{~mm}$. Both sexes of $T$. brunnea are similar in color. The carapace and legs are uniformly yellow-orange to orange. The abdomen is dark gray with lateral white patches and posterior chevrons dorsally, and a pair of pale spots on the venter. However, specimens from peninsular Florida frequently lack abdominal markings. In general, $T$. brunnea is smaller and more brightly colored than $M$. simoni.

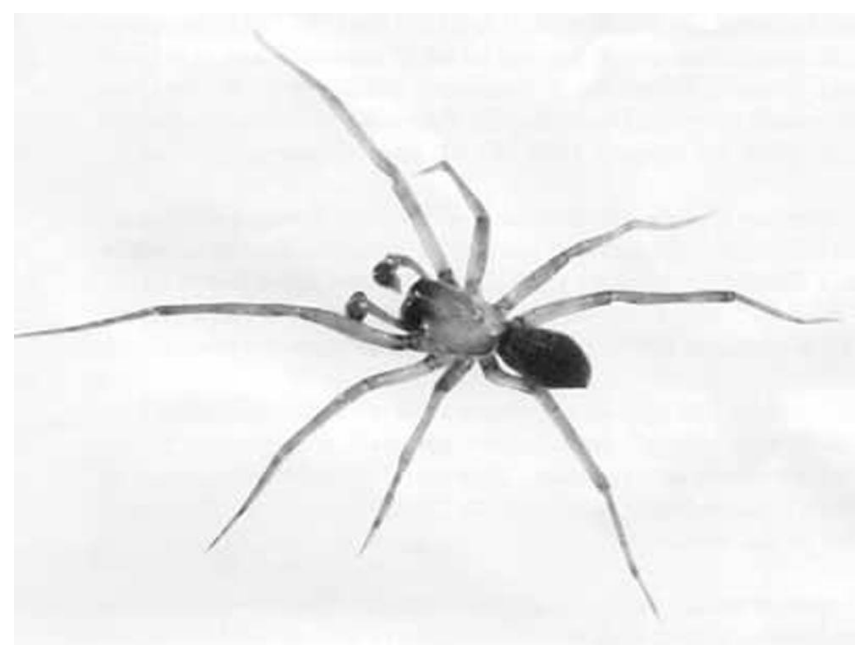

Figure 1. Male Metaltella simoni (Keyserling), a Cribellate spider. Credits: Photograph by: G.B. Edwards, Division of Plant Industry

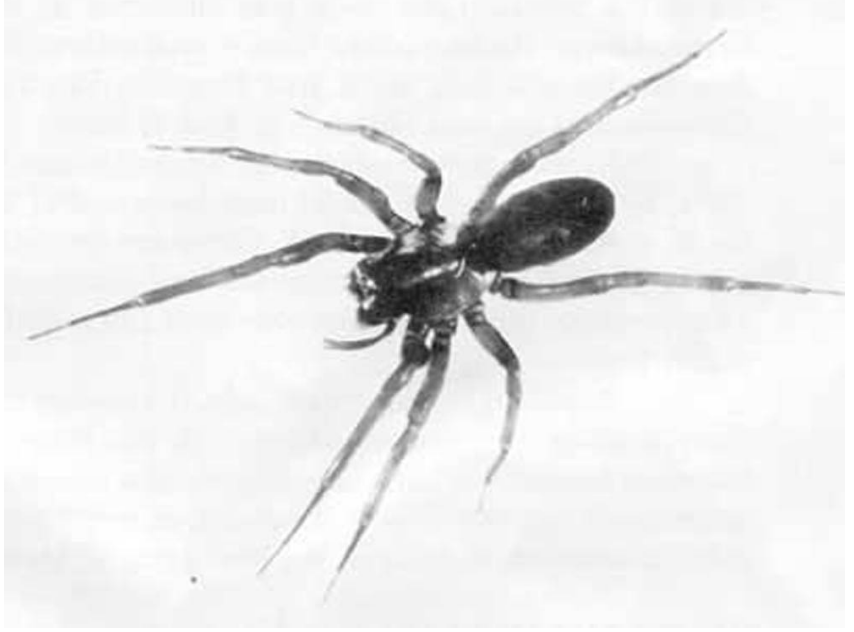

Figure 2. Female Metaltella simoni (Keyserling), a Cribellate spider. Credits: Photograph by: G.B. Edwards, Division of Plant Industry

\section{Habits and Habitat}

Females and juveniles of $M$. simoni make webs using cribellate silk which, although smaller, are similar to those made by the southern house spider, Kukulcania (formerly Filistata) hibernalis (Edwards 1983, Roth 1985). Spiders may be found under logs, 
with the web attached to log and ground (Leech 1972), under bark, under boards and boxes, in crevices and corners in buildings, or, in the case of males, wandering around. Almost nothing is known about the life history of this species. There does not appear to be any biological information, such as number of young or type of prey, in the literature. Based on the records in the FSCA, most males have been collected in May, June, or July, although individuals have been found from February to October. FSCA records of females include the months January, February, April, May, and August. It seems likely that adults of both sexes can be found in any month of the year in Florida.

One cause for concern about the presence of $M$. simoni in Florida is its potential effect on our only native amaurobioid, Titanoeca brunnea Emerton. Although T. brunnea is widespread in the eastern U.S., it only has been reported from Alachua, Hernando, and Putnam Counties in Florida (Leech 1972). The five FSCA records are from Alachua, Columbia, and Putnam Counties. The most recent record for T. brunnea in the FSCA is from western Alachua County, Green Acres, 8 February 1979, by G. Davidson, six males in a pitfall trap. There is also one earlier record with "habitat" data: Alachua County, Gainesville, 5 May 1964, collected by K.J. Stone, one male in a house. FSCA records for $T$. brunnea range from February to June. D.T. Corey (personal communication) has the following additional records: two males, Suwannee County, Suwannee River State Park, one May 1987; one male, also Suwannee River State Park, 28 April 1988; one male, Alachua County, Gainesville, 10 July 1987; one male Pasco County, New Port Richey, 6 May 1988; one female, Polk County, Lake Wales, 14 November 1986. Four new counties (Columbia, Pasco, Polk, and Suwannee) are added to the known Florida distribution of T. brunnea. All of Corey's records are from pitfall traps, in several cases from the same localities and collection dates as M. simoni. I have examined Corey's specimens and confirmed his records.

Leech (1972) reported T. brunnea as an inhabitant of leaf litter, whereas $M$. simoni apparently uses some larger structural feature, such as a log or board, from which to base its web. Is this a sufficiently distinct microhabitat difference to prevent competition between the two species? The last FSCA record of T. brunnea was from 1979, at approximately the same time that $M$. simoni began dispersing into peninsular Florida. Until recently, this seemed to indicate that $M$. simoni was displacing $T$. brunnea. All of the records of M. simoni from peninsular Florida have been since 1980, from situations similar to those previously reported for $T$. brunnea. However, the latter collections by Corey seem to indicate that the two species coexist.

\section{Selected References}

Corey DT, Taylor WL. 1988. Ground surface spiders in three central Florida plant communities. Journal of Arachnology 16: 213-221.

Corey DT, Taylor WK. 1989. Foliage-dwelling spiders in three central Florida plant communities. Journal of Arachnology 17: 97-106.

Corey DT, Stout IJ, Edwards GB. 1998. Ground surface spider fauna in sandhill communities of Florida. Journal of Arachnology 26: 303-316.

Edwards GB. 1983. The southern house spider, Filistata hibernalis Hentz (Araneae: Filistatidae). Florida Department of Agriculture and Consumer Services, Entomology Circular 255: 1-2.

Leech, R. 1972. A revision of the Nearctic Amaurobiidae (Arachnida: Araneida). Memoirs of the Entomological Society of Canada 84: 1-182.

Roth, V.D. 1985. Spider genera of North America. Privately published, Portal, AZ. 